\title{
Where Teachers Thrive: A Book Review
}

\author{
William Waychunas*
}

* University of Michigan, Educational Studies, Ann Arbor, United States E-mail: billway@umich.edu

\section{Article Info}

Received: August 30, 2020

Revised: December 3, 2020

Accepted: December 10, 2020

\subsection{3/repam.2020.7}

\section{How to cite}

Waychunas, W. (2020). Where Teachers Thrive: A book review. Research in Educational Policy and Management, 2(2), 129-132.

https://doi.org/10.46303/repam.2020.7

\section{Copyright license}

This is an Open Access article distributed under the terms of the Creative Commons Attribution 4.0 International license (CC BY 4.0).

\begin{abstract}
This article reviews the book Where Teachers Thrive: Organizing Schools for Success written by Dr. Susan Moore Johnson and published in 2019. By describing the content of each chapter as well as the overall contributions of this recent book to knowledge about the interaction between school contexts, policy environments, and teacher experience, this review provides readers with a taste of this groundbreaking work while also offering analysis and minor critiques.

KEYWORDS

School organization; School leadership; Hiring; Collaboration; Book review.
\end{abstract}




\section{BOOK UNDER REVIEW}

Where Teachers Thrive: Organizing Schools for Success, by Susan Moore Johnson, Cambridge, MA: Harvard Education Press, 2019, 320 pp., \$34.00 (paperback), ISBN: 978-1-68253-358-1

2020 PROSE Award Winner, Education Theory Category

2019 Outstanding Academic Title, Choice

\section{REVIEW, ANALYSIS, AND CRITIQUE}

Susan Moore Johnson's refreshingly written new book (2019) is a rare text that is truly useful to a range of audiences in education, bridging often disconnected fields of education reform, policy, school leadership, and instruction to examine school-level factors that make or break teachers and schools. Do not be alarmed; this is not yet another lifeless autopsy documenting failed reforms with sterile and detached descriptions of school organization and policy implementation. Instead of portraying teachers as captives of their context, the author breathes life into the book by looking at schools and teachers more holistically, grounding her work in the teachers' voices and experiences. In doing so, this book makes a forceful argument that teachers are both shapers of and shaped by their school contexts and that the success of the teacher, school, and student are interdependent.

The book compiles data from three studies examining urban schools, serving mostly students of color in working-class communities. Though the overall lack of suburban or rural schools and exclusion of high schools in one study raises generalizability questions, the work is nonetheless impressive. Reminiscent of Samuel Casey Carter's book (2000) exploring schools that were "beating the odds" to identify effective practices, Johnson shares exquisitely detailed examples of converging practices that created these environments where teachers thrive, albeit with more of a focus on school organization than Carter's emphasis on principals.

Chapter one examines recruitment and hiring, emphasizing how successful schools use information-rich (Liu \& Johnson, 2006) processes, such as demonstration lessons, to ensure a match between teachers and schools in terms of mission and expectations. Human capital efforts serve as the foundation upon which such successful schools are built, likely why the author chose to lead with this chapter.

The second chapter tackles instructional autonomy in an era of accountability. Johnson emphasizes how curricular materials can both enable and constrain teachers, requiring a delicate balance in providing teachers with both discretion and direction. In particular, alignment of the school's mission with resources and support systems, such as collaboration and coaching, unlocked instructional capacity when schools were "developing and implementing a curriculum with teachers, rather than for or despite them" (p. 76).

The author takes up teacher collaboration in the third chapter, showing how successful schools break down traditional professional norms of isolation and privacy with teacher teams. Relatedly, chapter six discusses teacher leadership, highlighting the crucial role that principals 
play in empowering teacher voice as administrators and teachers work together towards creating and achieving the school's mission.

Meeting student needs is the focus of the fourth chapter, detailing how schools collectively approached student discipline and other development areas.

Chapter five, aptly titled Using Evaluation to Improve Instruction, touches on exemplary practices for formative teacher supervision approaches that drive teachers' growth. Increasing the frequency of observations, improving the quality of feedback, and connecting other supports with identified needs made observations more aligned with school goals, more about development, and less about compliance and dismissal while feeling more "fair" to teachers.

The nuts and bolts of school logistics are the focus of the final two chapters. Chapter eight explores how schools organize schedules, course assignments, and meetings to ensure that, as the chapter title suggests, schools are Making the Most of Teachers' Time. The final area discussed is teacher pay, comparing traditional pay scales with merit-based and multiple-path approaches.

Though administrators did not receive their own chapter, principal leadership in promoting the school vision, their reputations as instructional experts, and their approach to relationships in working with and empowering teachers rang present in every single chapter.

Instead of thinking of these factors as independent programs at schools, Johnson paints a picture showing how they "are entwined and interdependent," supporting claims that "...for instruction to be effective it ha[s] to be grounded in a deliberately structured, supported, and sustaining school organization that focused on learning" (p. 235). Though "not a book with a simple punch line or a slam-dunk solution," the book leaves readers with a broad vision that, while "demanding and complex," is "not unknowable or undoable" (p. 246).

Some areas of this book leave readers with questions to ponder, especially in how teacher "thriving" is defined. Is thriving based solely on teacher satisfaction or other outcomes too? It seemed as though professional growth, student learning, and job satisfaction were part of Johnson's conception, but it would help future work to clarify ideas about what makes a "good" school or a "thriving" teacher.

Readers are also left waiting for bold statements about necessary changes in schools that seem to be logical conclusions. The problems with traditional professional norms of teaching and how they harm teachers, schools, and students seemed to be on the tip of the author's tongue but are never directly tackled, leaving readers with a desire for a more clear declaration or new conceptualization of teacher professionalism. Similarly, the book was too soft on systemic obstacles preventing schools from enacting the suggested policies. A stronger stance condemning how schools and teachers often get in their own ways when it comes to simple changes, such as in hiring processes or school schedules, seemed appropriate but was strangely absent.

The book's final section, titled "It Can't Be Done on the Cheap," which called for increased school funding, was a bizarre way to close out the book. While there is no doubt that money 
matters in education, it seems odd to conclude a book about school organization and teacher empowerment with arguments for broad increases in spending when a clear takeaway from the book was that resources mean little in the hands of demoralized teachers or unorganized schools.

These critiques, however, are minuscule, even bordering on petty. Like few other works before, this book gracefully bridges areas within education to add to our understanding of school organization and teacher experience.

\section{REFERENCES}

Carter, S. C. (2000). No excuses: Lessons from 21 high-performing, high-poverty schools. Heritage Foundation: Washington, DC.

Johnson, S. M. (2019). Where teachers thrive: Organizing schools for success. Harvard Education Press.

Liu, E., \& Johnson, S. M. (2006). New teachers' experiences of hiring: Late, rushed, and information-poor. Educational Administration Quarterly, 42(3), 324-360. 